\title{
在西准噶尔晚泥盆世陆相地层中发现首例缺棘 短胸节甲鱼类
}

刘一龙 ${ }^{1}$, 纵瑞文 ${ }^{2}$, 龚一鸣 ${ }^{1,2 *}$

1. 中国地质大学(武汉)地球科学学院, 武汉 430074;

2. 中国地质大学, 生物地质与环境地质国家重点实验室, 武汉 430074

*联系人, E-mail: ymgong@cug.edu.cn

2020-02-10 收稿, 2020-04-05 修回, 2020-04-08 接受, 2020-04-14 网络版发表 国家自然科学基金(41872034，41702006，41290260)资助

摘要记述了新疆西准噶尔晚泥盆世早法门期月骨鱼科(属于盾皮鱼纲节甲鱼目短胸节甲鱼亚目缺棘短胸节甲鱼 超科)一新属——布龙鱼(Bulongosteus gen. nov.). 新属发现于朱鲁木特组上部辫状河相砾岩和含砾砂岩中, 新属的 主要特征是: 中颈片呈前缘前凹、后缘前凹的三角形, 两侧微内凹; 副颈片后缘超过中颈片后缘, 发育两条感觉管; 眶前片加大以致形成眼眶的前背缘, 表面具有较为密集的瘤点; 缘片前缘加厚形成眼眶后缘, 3 条感觉管呈明显“ “Y” 字形; 后腹侧片细长. 布龙鱼是在新疆首次发现的节甲鱼类, 也是缺棘短胸节甲鱼类在陆相沉积中的首次发现, 丰 富了我国缺棘短胸节甲鱼类的化石记录，扩展了缺棘短胸节甲鱼类的地理分布和生态范围，也表明缺棘短胸节甲 鱼类同晚泥盆世众多鱼类一样也是一类广盐性鱼类.

关键词盾皮鱼类, 短胸节甲鱼类, 布龙鱼, 晚泥盆世, 河流相, 西准噶尔

盾皮鱼类(Placodermi)是泥盆纪“鱼类时代”多样性 最高的有领脊椎动物, 也是有领脊椎动物原始形态的 代表, 在古生物学和演化生物学上具有重要意义 ${ }^{[1 \sim 4]}$. 节甲鱼类(Arthrodira)是盾皮鱼类中分布最广、多样化 程度最高的类群 ${ }^{[5-8]}$, 约占已知盾皮鱼类的 $60 \%$, 在海洋 和淡水环境中均有分布. 目前对节甲鱼类的内部系统 关系已有一些共识 ${ }^{[9,10]}$, 特别是已识别出其中一个大的 单系类群, 即短胸节甲鱼类(Brachythoraci). 该类群躯甲 退化, 适应在中上层水体快速、灵活地游动. 短胸节甲 鱼类在中-晚泥盆世非常繁盛, 化石数量众多, 分布广 泛 $^{[1,11,12]}$. 短胸节甲鱼类包括粒骨鱼形类(Coccosteomorphs)、厚甲鱼形类(Pachyosteomorphs)和一些被归 为基干短胸节甲鱼类的原始属种，其中前两个类群组 成了真短胸节甲鱼次目(Eubrachythoracids). 在真短胸
节甲鱼类中，厚甲鱼形类和粒骨鱼形类之间的姐妹群 关系已经得到了大多数系统发育分析的支持, 但是这 两个类群内的基础成员和内部关系仍然存在不稳定 性 $^{[13 \sim 16]}$.

厚甲鱼形类和粒骨鱼形类是中-晚泥盆世最繁盛的 节甲鱼类类群, 其在淡水和海洋中均有分布, 其中的粒 骨鱼形类在湖相和滨-浅海相地层中均有发现, 而厚甲 鱼形类大都只保存在海相地层中. 月骨鱼类作为厚甲 鱼形类中研究程度较高的一个科, 报道的化石材料主 要分布在欧洲、北美和北非的海相地层中 ${ }^{[1,12,15,17,18]}$. 王俊卿和朱敏 ${ }^{[19]}$ 在我国湖南晚泥盆世写经寺组发现了 疑似月骨鱼类的中颈片，定名为刘氏瘤骨鱼(Phymosteus liui Wang et Zhu 2004), 但由于材料只有一件中颈 片, 提供的鉴定特征太少, 所以该种的确切分类位置还 
有待进一步确定. 本研究描述的来自新疆西准噶尔地 区的鱼化石既是新疆的第一个节甲鱼类，也是我国第 一个较完整的缺棘短胸节甲鱼类，更是世界上第一个 在陆相沉积中发现的缺棘短胸节甲鱼类.

\section{1 地质背景与材料}

本研究报道的鱼化石材料发现于新疆和布克赛尔 蒙古自治县和什托洛盖镇布龙果尔水库以北 $1.5 \mathrm{~km}$ 处 的布龙果尔剖面(图1(a), (b)). 地层分区属于北疆地层 区北准噶尔地层分区沙尔布尔提山地层小区 ${ }^{[20]}$, 本区 出露地层以志留系-泥盆系分布最为广泛, 其中, 上泥 盆统包括朱鲁木特组和洪古勒楞组. 朱鲁木特组主要
分布在沙尔布尔提山及谢米斯台山南北侧, 为陆相磨 拉石或类磨拉石，局部夹少量的火山岩及钙质碎屑岩， 植物化石丰富. 布龙果尔地区的朱鲁木特组呈近南北 向展布, 下伏地层未出露, 上覆地层为上泥盆统洪古勒 楞组(图1(c))，通过探槽揭露，二者之间呈整合接触关 系. 朱鲁木特组主要岩性以砾岩、含砾砂岩和中粗粒 砂岩为主, 细砂岩和粉砂岩较少. 在横向上岩性组合无 太大变化, 均发育不太典型的二元结构, 粗部或下部较 厚, 发育大型槽状、楔状或板状交错层理, 砾岩底部发 育冲刷构造，其中含有大量的植物化石Leptophloeum rhombicum Dawson等; 细部或上部较薄, 发育水平层 理和小型砂纹层理，粉砂岩中可见纤细的植物茎干或

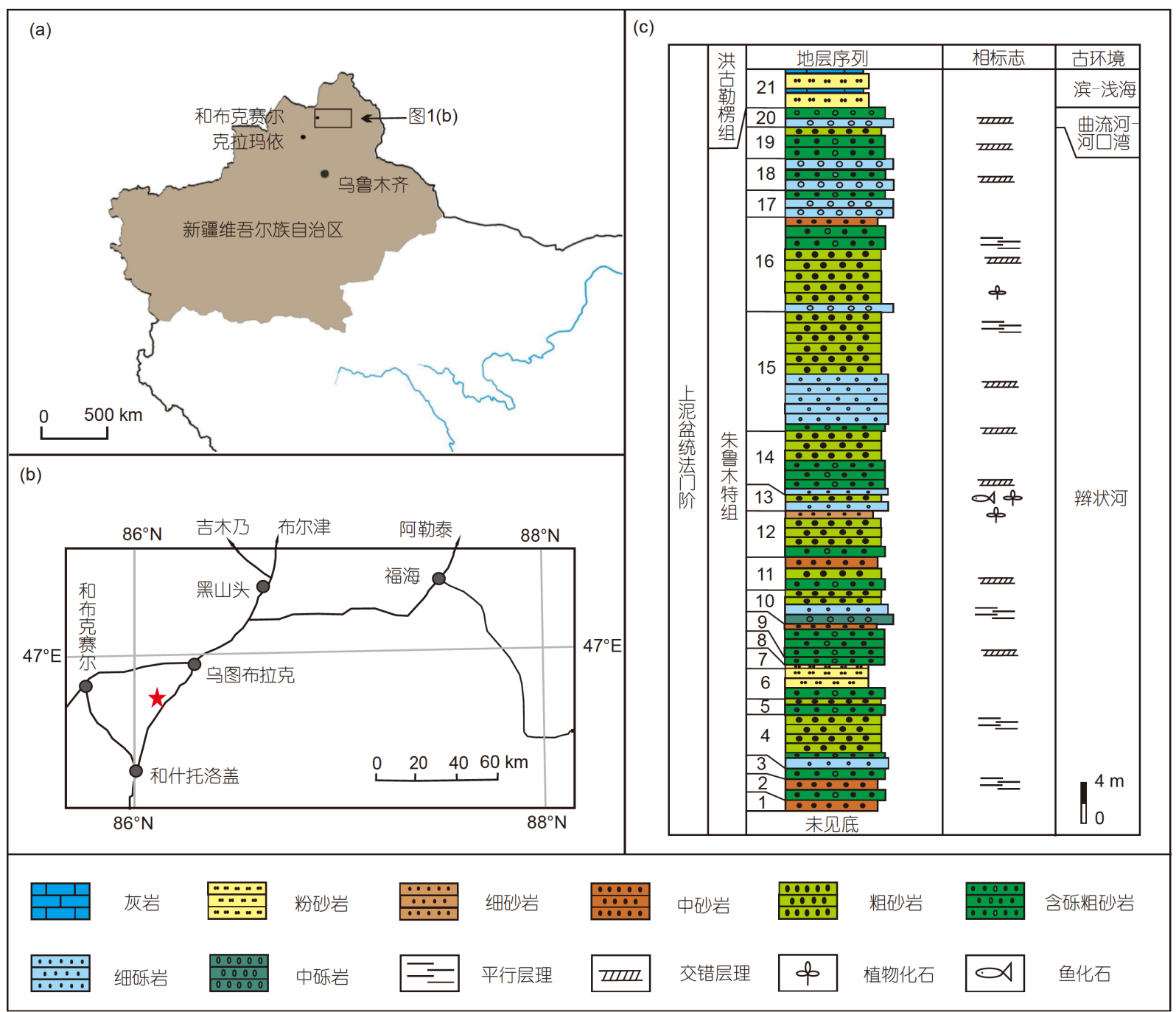

图 1 (网络版彩色)鱼化石产地、层位和古环境特征简图. (a), (b) 布龙果尔剖面地理位置图, (b)中五角星为布龙果尔剖面; (c) 晚泥盆世法门期 朱鲁木特组鱼化石产出层位与古环境

Figure 1 (Color online) Sketch showing the location, horizon and paleoenvironment of fish fossils. (a), (b) Schematic geographic map showing the Bulongguoer section (pentagram in (b)); (c) the horizon and paleoenvironment of fish fossils from the Upper Devonian Famennian Zhulumute 
叶的碎片. 这些特征表明, 布龙果尔地区的朱鲁木特组 形成于辫状河环境(图1(c)).

朱鲁木特组的鱼化石集中产于第12层的含砾粗砂 岩和第13层的细砾岩中, 第13层中的鱼化石数量较第 12层多. 化石均为保存不全的单个骨片, 其中多数分辨 不出骨片的类型, 保存的方式也较为分散. 本研究所采 集的标本在第13层局部富集保存, 且骨片组成比例相 似, 表面特征一致, 无重复的骨片, 表明这批鱼化石未 经历长距离的搬运, 属于原地异位保存.

朱鲁木特组是上泥盆统弗拉阶/法门阶 $(\mathrm{F} / \mathrm{F})$ 之交地 层, 从20世纪70年代就开始进行系统的地层学方面的 工作，但 $\mathrm{F} / \mathrm{F}$ 界线的位置现在仍存争议. 在布龙果尔剖 面, 夏风生 ${ }^{[21]}$ 根据牙形石的时代最早提出上覆的洪古 勒楞组包含一小部分弗拉期沉积; Chen等人 ${ }^{[22]}$ 和Suttner等人 ${ }^{[23]}$ 也曾报道洪古勒楞组底部含有晚弗拉期的 牙形石, 并认为弗拉阶与法门阶界线位于距洪古勒楞 组底部 $2.7 \mathrm{~m}$ 处. 但是, $\mathrm{Ma}$ 等人 ${ }^{[24]}$ 根据腕足类的研究则 认为布龙果尔剖面洪古勒楞组底部不含弗拉期沉积. 最近, 我们团队成员在布龙果尔剖面的洪古勒楞组最 底部的灰岩中处理出来的牙形石属于法门期Pa.crepi$d a$ 带的分子 ${ }^{[25]}$. 窦亚伟和孙喆华 ${ }^{[26]}$ 在研究新疆北部晚 古生代植物化石时, 将晚泥盆世植物群分为两个植物 组合: 亚鳞木-鞘木植物组合 (Sublepidodendron-Colpodexylon Assemblage) 和薄皮木-亚鳞木植物组合 (Leptophloeum-Sublepidodendron Assemblage), 前者相当于 弗拉期, 后者相当于法门期. 后一组合以Leptophloeum 的繁盛和Colpodexylon的缺失为主要特征, 其他成员与 前一组合基本一致. 朱鲁木特组含鱼层位中Leptophloeum rhombicum非常丰富, 与上述两个植物组合相比 更接近于薄皮木-亚鳞木组合. 因此, 本研究将这套含鱼 化石的地层时代定为早法门期.

\section{2 系统古生物学}

盾皮鱼纲 Placodermi McCoy, 1848

节甲鱼目 Arthrodira Woodward, 1891

短胸节甲鱼亚目 Brachythoraci Gross, 1932

真短胸节甲鱼次目 Eubrachythoraci Miles, 1971

厚甲鱼形次亚目 Pachyosteomorphi Stensiö, 1944

缺棘短胸节甲鱼超科 Aspinothoracidi Stensiö, 1959(sensu Miles and Dennis, 1979)

月骨鱼科Selenosteidae Dean,1901(sensu Le- lièvre et al.,1987)

布龙鱼(新属)Bulongosteus gen. nov.

词源 Bulong $(\mathrm{Gr}$. $)$ 取产地布龙果尔中“布龙”二字拼 音, steus(Gr.)骨甲.

特征 见属型种

刘氏布龙鱼(新种) Bulongosteus liui sp. nov.

词源 种名为纪念中国最早研究短胸节甲鱼类化 石的古鱼类学家刘宪亭先生.

正型标本 一件中颈片, 标本登记号: B20-1.

归入标本 松散关联的头部和躯甲骨片, 中国地质 大学(武汉)生物地质和环境地质国家重点实验室标本 登记号: B20. 包括一件右眀下片(B20-3)、一件右眶前 片(B20-4)、一件吻片(B20-13)、一件右缘片(B20-5)、 一件右副颈片(B20-2)、一件中背片(B20-6)、一件前 背侧片(B20-7)、一件后侧片(B20-8)、一件左、右前 腹侧片(B20-9、10)、一件后中腹片(B20-12) 和一件左 后腹侧片(B20-11).

产地与层位 新疆维吾尔族自治区塔城地区和布 克赛尔蒙古自治县和什托洛盖镇布龙果尔水库, 上泥 盆统朱鲁木特组上部(早法门期).

特征 个体较大的厚甲鱼类. 中颈片呈前缘前凸、 后缘前凹的三角形, 两侧微内凹. 副颈片后缘超过中颈 片后缘, 发育两条感觉管. 眶前片加大以致形成眼眀的 前背缘, 表面具有较为密集的瘤点. 缘片前缘加厚形成 眼眀后缘，3条感觉管呈明显“Y”字形. 后腹侧片细长. 以中颈片两侧微内凹的三角形特征不同于 Microsteus、Enseosteus、Gymnotrachelus、Selenosteus、Stenosteus、Dragonichthys、Driscollaspis、Hlavinichthy、Paramylostoma; 以副颈片和缘片特有的感觉 管特征不同于Pachyosteus、Rhinosteus、Melanosteus、Walterosteus.

描述头甲骨片包括一件中颈片、右眭下片、右 眶前片、吻片、右缘片、右副颈片，躯干骨片包括中 背片、前背侧片、后侧片、前腹侧片、后中腹片和一 件左后腹侧片. 此次对具有新属种特征的部分骨片进 行描述, 同时根据所有骨片提供了刘氏布龙鱼复原图 (图2).

眶下片(B20-3, 图3(a) (d))形状呈“口哨状”. 骨片表 面具有3条感觉管, 眶下管眶下支(ioc.pt, 图3(a), (b))从 眶前区向后延伸到骨片中部; 眶下管(soc, 图3(a), (b))从 眶后区下缘向上延伸, 与眶下管眀下支相交于中部, 继 续向眶后区上缘延伸形成眀下管眀后支(ioc.pt，图3(a), 


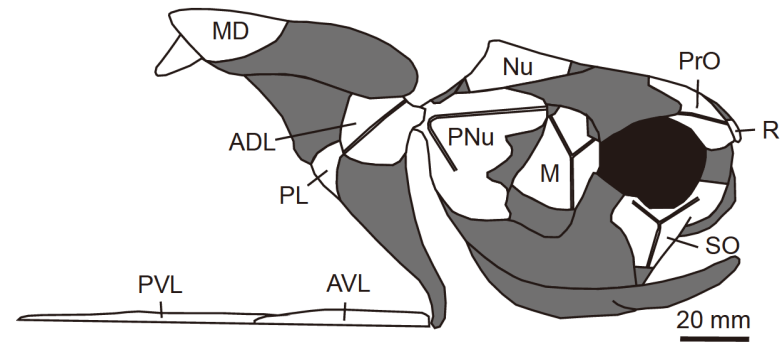

图 2 刘氏布龙鱼(新属, 新种)头甲和躯甲复原右侧视图, 实际保存 部分显示为白色. ADL, 前背侧片; $\mathrm{AVL}$, 前腹侧片; $M$, 缘片; $M D$, 中 背片; $\mathrm{Nu}$, 中颈片; PL, 后侧片; PNu, 副颈片; PrO, 眶前片; PVL, 后腹 侧片; R, 吻片; SO, 眶下片

Figure 2 Recuperative head and trunk shield of Bulongosteus liui (gen. et sp. nov.) in right lateral view, the preserved parts are shown in white. ADL, anterior dorsolateral plate; AVL, anterior ventrolateral plate; M, marginal plate; $\mathrm{MD}$, median dorsal plate; $\mathrm{Nu}$, nuchal plate; $\mathrm{PL}$, posterior lateral plate; $\mathrm{PNu}$, paranuchal plate; $\mathrm{PrO}$, preorbital plate; $\mathrm{PVL}$, posterior ventrolateral plate; $\mathrm{R}$, rostral plate; $\mathrm{SO}$, suborbital plate

(b)). 内面具有融合的眶下崉(cr.so, 图3(c), (d))和眀后揹 (cr.po, 图3(c), (d)), 形成眀穹窒的腹侧和后缘, 眶后嵴 向后逐渐变窄. 腹侧, 自腭骨凹(a.au, 图3(c), (d))将眀下

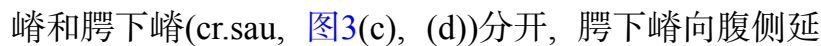
伸，横向形成舌形突(pr.ling，图3(c)，(d))，与后上领片 相连 ${ }^{[5]}$.

副颈片(B20-2，图3(e) (h)) 为不规则的四边形，构 成颅骨顶部的后外侧边缘. 骨片前缘未保留, 但可推测 与缘片相接触，后缘存在明显的后颈突(pnp，图3(e) (h))和关节窝 (laf，图3(e) (h))，关节窝与躯甲前背侧片 的髁突相关节，上缘为中颈片覆压区(Nu.oa，图3(g), (h)). 骨片表面存在两条感觉管, 即主侧线管(lc, 图3(g), (h))和后点线管 $(\mathrm{pp}$, 图 $3(\mathrm{~g})$, (h)), 后者从主要侧线管向 前分支，呈弧形接触. 骨化中心位于骨片中心后下缘. 骨片内表面其后下方明显加厚，形成一加厚嵴(PNu.th, 图3(e)，(f))，向前缘骨片逐渐变薄，大体形成一勺形凹 坑，凹坑后下缘外壁较陡，其他部位较平滑，下缘存在 后边缘片接触面(cf.PM, 图3(e), (f)).

中颈片(B20-1, 图3(i) (n))形状近三角形, 后缘明显 前凹, 呈圆弧状, 并具小的后中突(p. pr, 图3(i) (1)), 后缘 两侧部分缺失. 从后面看, 后中突的两侧隐约可见一对 浅坑(dp. mc, 图3(k), (l)), 其有可能是头甲举肌前端的 固着点. 在中颈片的后坑两侧, 后降叶(pdl, 图3(i) (1))下 方各有一个横长的凹槽(pnp. gr, 图3(i) (1)), 向两侧延 伸，推测可以一直到中颈片后侧角的顶端，副颈片的后 颈突就镶嵌在此槽内，可以表明副颈片的后颈突十分 发育．骨片两侧缘的覆压副颈片(cf.PNu，图3(m)，(n)),
覆压区的中部宽，两部窄. 从腹面看，中颈明显加厚(n. th, 图3(m), (n)), 由骨片后侧角向前中方向延伸, 大致与 侧缘平行, 中颈加厚之间有一横置的凹槽, 该槽后壁陡, 前壁较缓，其中间的中隔嵴(m. sept，图3(m)，(n))未保 存，理论上中隔嵴应将此凹槽分为一对深而圆的凹窝 (pt. u, 图3(m)，(n)). 其凹窝较深，呈三角雉形，顶端指 向骨片背面, 顶部尖, 底部宽. 在凹窝之后, 后横脊(p. tr. $\mathrm{r}$, 图3(m), (n))较发育.

缘片(B20-5, 图3(o), (p))呈四边形, 长大于宽. 前缘 与眶后片构成眼眀的后缘，下边缘片覆压缘片的前缘 下部形成下边缘片覆压区(SM.oa, 图3(o)). 在缘片表面 存在3条感觉沟, 包括眶下管耳支(ioc.ot, 图3(o))、主侧 线管(lc，图3(o))和后边缘管(pmc，图3(o))，三者之间相 互接触，呈典型的“Y”字。骨片后缘内面存在弧形的副 颈片接触面( $\mathrm{cf} . \mathrm{PNu}$, 图3(p)), 向前缘逐渐增厚, 形成颉 骨顶部的横向固结部分, 厚约 $2.5 \mathrm{~cm}$.

眶前片(B20-4，图4(a) (c))呈五边形，构成颖顶的 前外侧边缘和眼眭的前内侧边缘. 表面具有从前缘向 眼眀外缘延伸的眶上管(soc，图4(a))，整体表面饰有小 而密集的瘤点. 其前边缘略微向下弯曲, 形成眶的前边 缘和眶下片的接触面(cf.SO, 图4(b)).

中背片(B20-6, 图4(d) (f))仅保留骨片的部分后缘, 后缘呈弧形，骨片内面可见一条沿中线保存的龙骨嵴 (kv，图4(e))印痕，后缘龙骨突(cr.pr，图4(d) (f))保存不 完全, 从现有标本判断龙骨突超出中背片后缘.

后腹侧片(B20-11，图4(g)，(h))的实体保存不完整， 印模保存完整. 骨片整体呈细长的三角形, 稍向上弯曲 拱起. 外表面光滑, 无纹饰. 内表面存在一横穿骨片的 加厚哙(PVL.th, 图4(g), (h)), 起加固骨片的作用.

比较 新材料的中颈片后部横向加宽侧向扩展, 内 面横向增厚且具有成对的举肌坑，副颈片具有后颈突， 眶前片加大以至形成眼眀的前背缘，眶前片存在眶前 突且前缘与眶下片接触，副颈片与中颈片接触部分的 后缘存在超出中颈片后缘的后颈突符合节甲鱼目短胸 节甲鱼亚目中的真短胸节甲鱼次目的特征 ${ }^{[8,27,28]}$. 从中 颈片后部前凹形成宽大的颈缺，中颈片呈三角形，副颈 片具有后颈突，中背片内面存在发达的勺状龙骨嵴等 特征可知新材料符合厚甲鱼形次亚目的特征.

而新材料中的中颈片后缘明显前凹，颈缺较大，眼 眀大, 后腹侧片细长, 眶前片、眶后片和中央片三者界 点在眶孔前后缘之间符合厚甲鱼类中缺棘短胸节甲鱼 超科的特征．缺棘短胸节甲鱼超科包括Selenosteidae、 
(a)

(b)
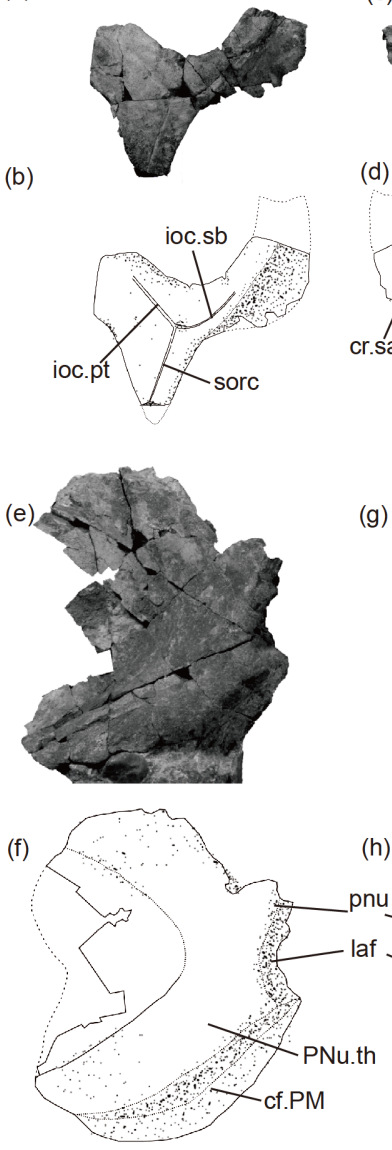

(d)

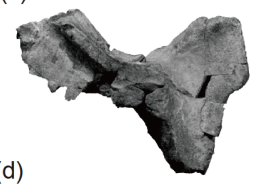

cr.sau pr.ling

(g)

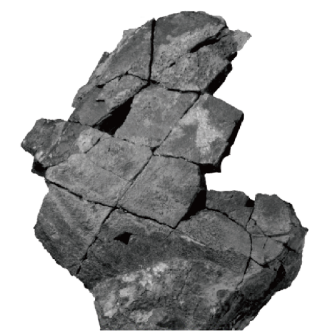

(h)

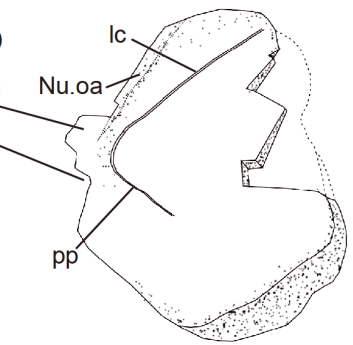

(I)
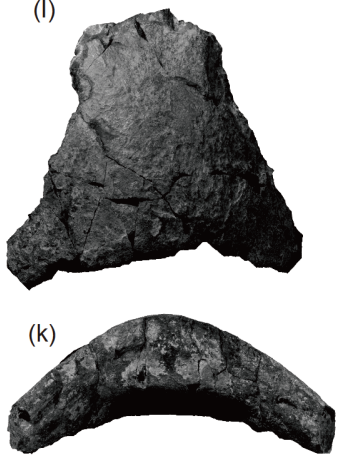

(m)

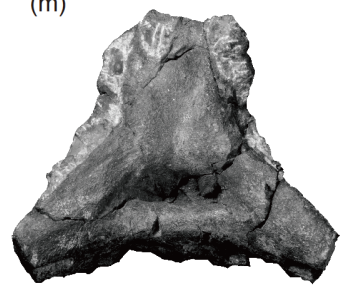

(o)

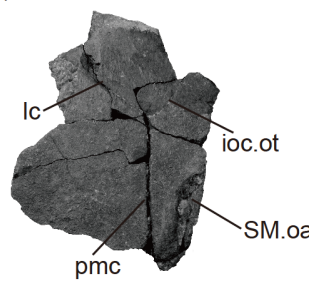

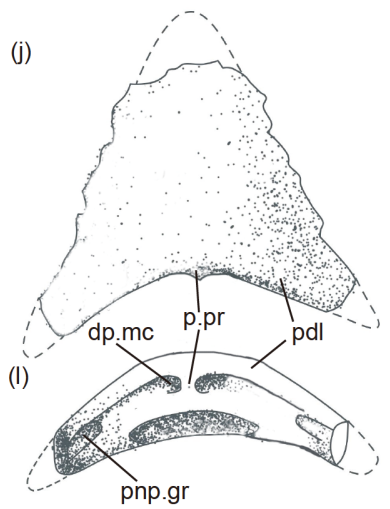

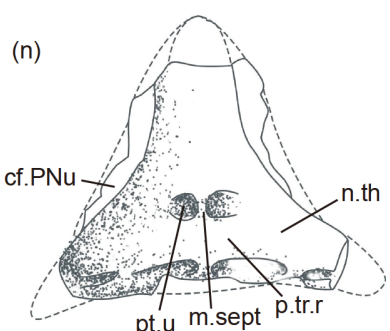

(p)

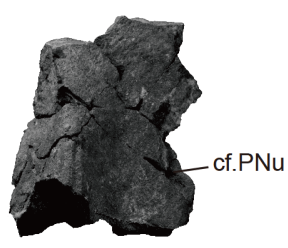

图 3 刘氏布龙鱼(新属, 新种)-1. (a) (d) 眭下片, B20-3: (a), (b) 背视图; (c), (d) 内视图. (e) (h) 副颈片, B20-2: (e), (f) 内视图; (g), (h) 背视图. (i) (n) 中颈片, B20-1: (i), (j) 背视图; (k), (1) 后视图; (m), (n) 内视图. (o), (p) 缘片, B20-5: (o) 背视图; (p) 内视图. cf.PM, 后边缘片接触面; cf. PNu, 副颈片接触面; cr.po, 眶后嵴; cr.sau, 腭下嵴; cr.so, 眶下嵴; dp. mc, 中颈片后坑; ioc.ot, 眶下管耳支; ioc.pt, 眶下管眶后支; ioc.sb, 眶下管眶下支; laf, 关节窝; lc, 主侧线管; m.sept, 中隔嵴; Nu.oa, 中颈片覆压区; n.th, 中颈加厚; PNu.th, 副颈片腹壁增厚嵴; pdl, 㐿顶甲后降叶; pmc, 后边缘管; pnp, 副颈片后颈突; pnp.gr, 与副颈片后颈突相接触的沟; pp, 后点线管; p.pr, 中颈片中后突; pr.ling, 舌形突; p.tr.r, 后横㙽; pt.u, 中颈片内面凹窝; SM.oa, 下缘片覆压区; sorc, 眶下管

Figure 3 Bulongosteus liui (gen. et sp. nov.)-1. (a)-(d) Suborbital plate, B20-3: (a), (b) In dorsal views; (c), (d) in internal views. (e)-(h) Paranuchal plate, B20-2: (e), (f) In internal views; (g), (h) in dorsal views. (i)-(n) Nuchal plate, B20-1: (i), (j) In dorsal views; (k), (l) in posterior views; (m), (n) in internal views. (o), (p) Marginal plate, B20-5: (o) In dorsal view; (p) in internal view. cf.PM, contact face for postmarginal plate; cf. PNu, contact face for paranuchal plate; cr.po, postocular crista; cr.sau, subautopalatine crista; cr.so, subocular crista; dp. mc, depression in posteromedian cusp of nuchal plate; ioc.ot, otic branch of infraorbital canal; ioc.pt, postorbital branch of infraorbital canal; ioc.sb, suborbital branch of infraorbital canal; laf, lateral articular fossa; lc, main lateral line canal; m.sept, median septum; Nu.oa, overlap area for nuchal plate; n.th, nuchal thickening; PNu.th, ventral thickening of paranuchal plate; pdl, posterior descending lamina of skull roof; pmc, postmarginal sensory canal; pnp, postnuchal process of paranuchal plate; pnp.gr, contact groove for postnuchal process of paranuchal plate; pp, posterior pitline groove; p.pr, median posterior process of nuchal plate; pr. ling, linguiform process; p.tr.r, posterior transverse ridge; pt.u, paired pits on visceral surface of nuchal plate; SM.oa, overlap area for submarginal plate; sorc, supraoral sensory canal

Hadrosteidae和曾归人Dinichthyidae的部分属种, 如 $D i$ nichthys herzeri Newberry 1868、Heintzichthys gouldii Newberry 1885、Gorgonichthys clarki Claypole 1892、 Holdenius holdeni Dunkle et Bungart 1942 ${ }^{[29]}$, 现研究表 明Heintzichthys gouldii Newberry 1885和Gorgonichthys clarki Claypole 1892属于Selenosteidae ${ }^{[15]}$.

在缺棘短胸节甲鱼超科中，拥有中颈片呈前缘前
凸、后缘前凹的三角形，眶前片中等大小，眼睈大，缘 片前缘加厚形成眼眀后缘，眶下感觉管眀后支与眭下 感觉管耳支之间的夹角为锐角特征的属种是月骨鱼科. 其中拥有中颈片呈三角形, 后颈突不明显, 眶下片明显 发育3支感觉管特征的属种有Pachyosteus、Rhinosteus、Melanosteus、Walterosteus这4个属. Rhinosteus其 骨片表面分布少量瘤点, 且副颈片的感觉管分布与新 
(a)

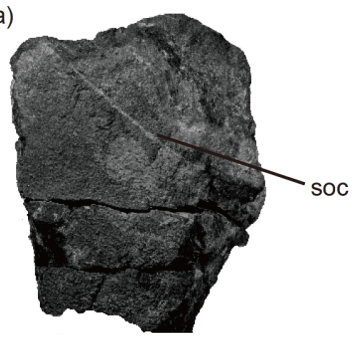

(b)

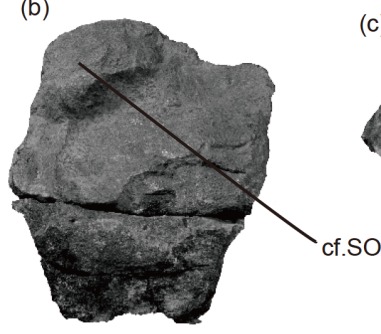

(d)

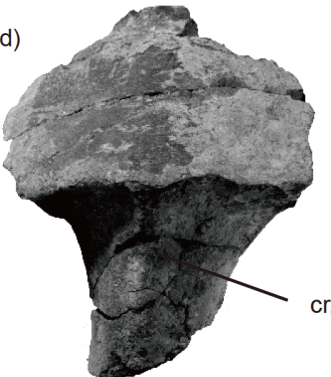

(g)

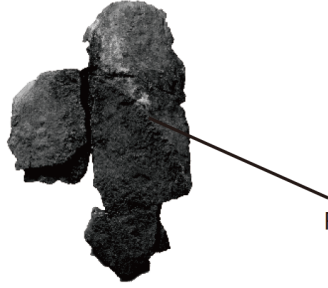

(c)

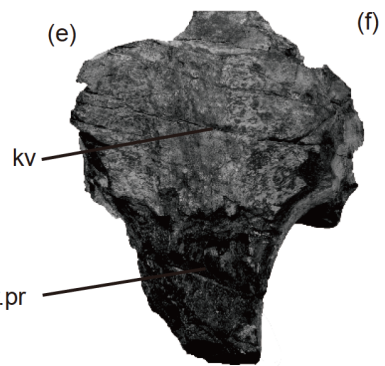

(f)
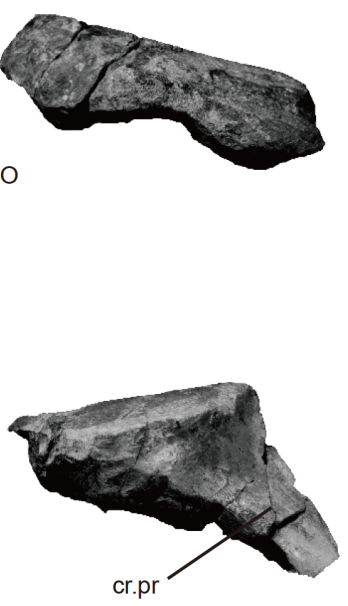

(h)

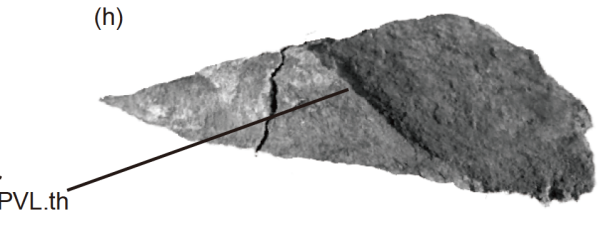

$20 \mathrm{~mm}$

图 4 刘氏布龙鱼(新属, 新种)-2. (a) (c) 诓前片, B20-4: (a) 背视图; (b) 内视图; (c) 侧视图. (d) (f) 中背片, B20-6: (d) 背视图; (e) 内视图; (f) 侧视 图. (g), (h) 后腹侧片, B20-11: (g) 内视图; (h) 外膜内视图. cf.SO, 眶下片接触面; cr.pr, 龙骨突; kv, 中背片龙骨嵴; PVL.th, 后腹侧片腹壁增厚嵴; soc, 眶上管

Figure 4 Bulongosteus liui (gen. et sp. nov.)-2. (a)-(c) Preorbital plate, B20-4: (a) In dorsal view; (b) in internal view; (c) in lateral view. (d)-(f) Median dorsal plate, B20-6: (d) In dorsal view; (e) in internal view; (f) in lateral view. (g), (h) Posterior ventrolateral plate, B20-11: (g) In internal view; (h) in internal view of outer membrane. cf.SO, contact face for suborbital plate; cr.pr, carinal process; kv, ventral keel of median dorsal plate; PVL.th, ventral thickening of posterior ventrolateral plate; soc, supraorbital sensory line

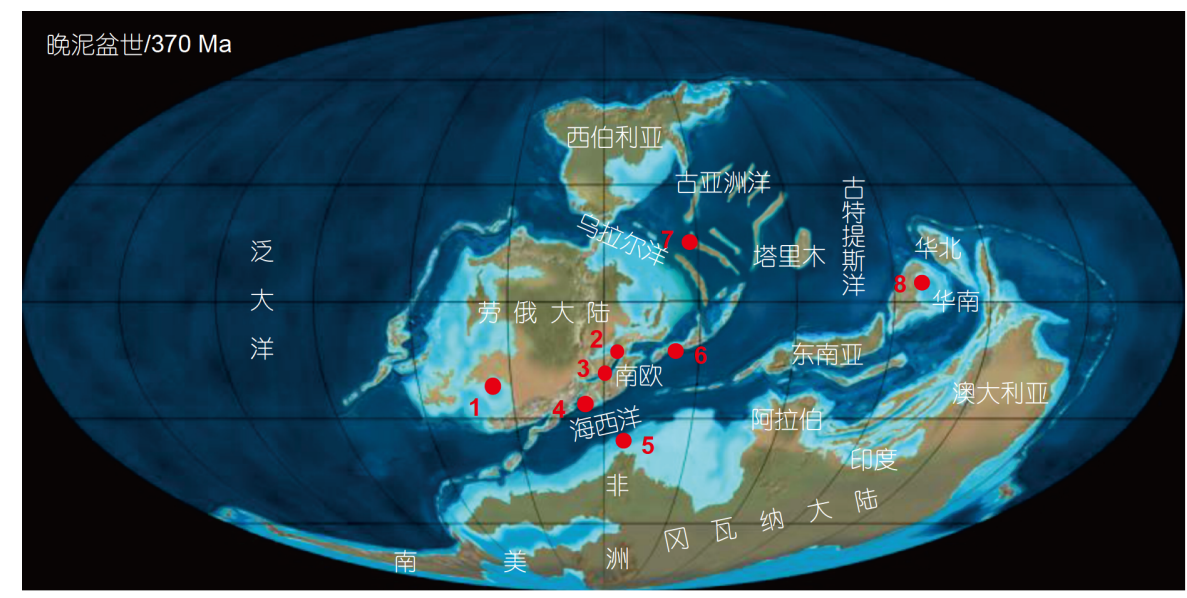

图 5 (网络版彩色)晚泥盆世缺棘短胸节甲鱼类的古地理分布(资料据文献[12,31]). 1, Ohio(美国); 2, Bad Wildungen(德国); 3, Bicken(德国); 4, Montagne Noire(法国); 5, Eastern Anti-Atlas(摩洛哥); 6, Holy Cross Mountains(波兰); 7, 西准噶尔; 8, 湖南

Figure 5 (Color online) Paleogeographic distribution of the Late Devonian Aspinothoracid ${ }^{[12,31]}$. 1, Ohio, USA; 2, Bad Wildungen, Germany; 3, Bicken, Germany; 4, Montagne Noire, France; 5, Eastern Anti-Atlas, Morocco; 6, Holy Cross Mountains, Poland; 7, western Junggar, China; 8, Hunan, central China 
疆标本不同; Walterosteus 的后缘比新疆标本的后缘更 宽，副颈片的感觉管分布与之亦不同. Pachyosteus和 Melanosteus 的特征与新疆标本最为相近，但Pachyosteus的中颈片有较少的瘤点, 吻片呈梯形, 副颈片的感 觉管分布亦不同; Melanosteus 在眀下片和眀前片部位 有一些瘤点分布，副颈片的感觉管分布与新疆标本不

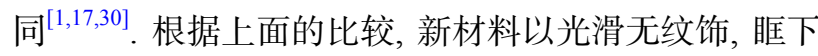
片、缘片和副颈片特殊的感觉管等特征同月骨鱼科已 描述的属种明显区分. 因此, 将新材料定名一新属.

\section{3 古生态与生物古地理}

厚甲鱼形类和粒骨鱼形类是中、晚泥盆世最繁盛 的节甲鱼类群, 其在河流、湖泊和海洋中均有分布, 其
中的粒骨鱼形类在湖相和滨-浅海相中均有发现，如在 澳大利亚西部的Gogo地区和苏格兰老红砂岩中，而厚 甲鱼形类大部分只保存在海相地层中. 厚甲鱼形类中 的缺棘短胸节甲鱼类仅在劳俄大陆东南缘、冈瓦纳大 陆北缘和古特提斯洋东部的华南地区的海相碳酸盐岩 或砂页岩中有报道, 其主要生活于中-低纬度的滨-浅海 表层水域(图5) ${ }^{[1,12,15,17 ~ 19]}$. 截至目前, 在北半球的古亚 洲洋构造域还未见报道. McKerrow等人 ${ }^{[32]}$ 曾提出假 设: 在海洋未闭合之前, 洋流是影响滨岸海生鱼类分布 的主控因素, 随着海洋的闭合, 控制生物地理分布的主 要因素越来越多地与气候和古地理的配置有关. 西准 噶尔晚泥盆世辫状河流相砂砾岩地层中(朱鲁木特组) 新材料的发现改写了厚甲鱼类环境分布的传统认识,

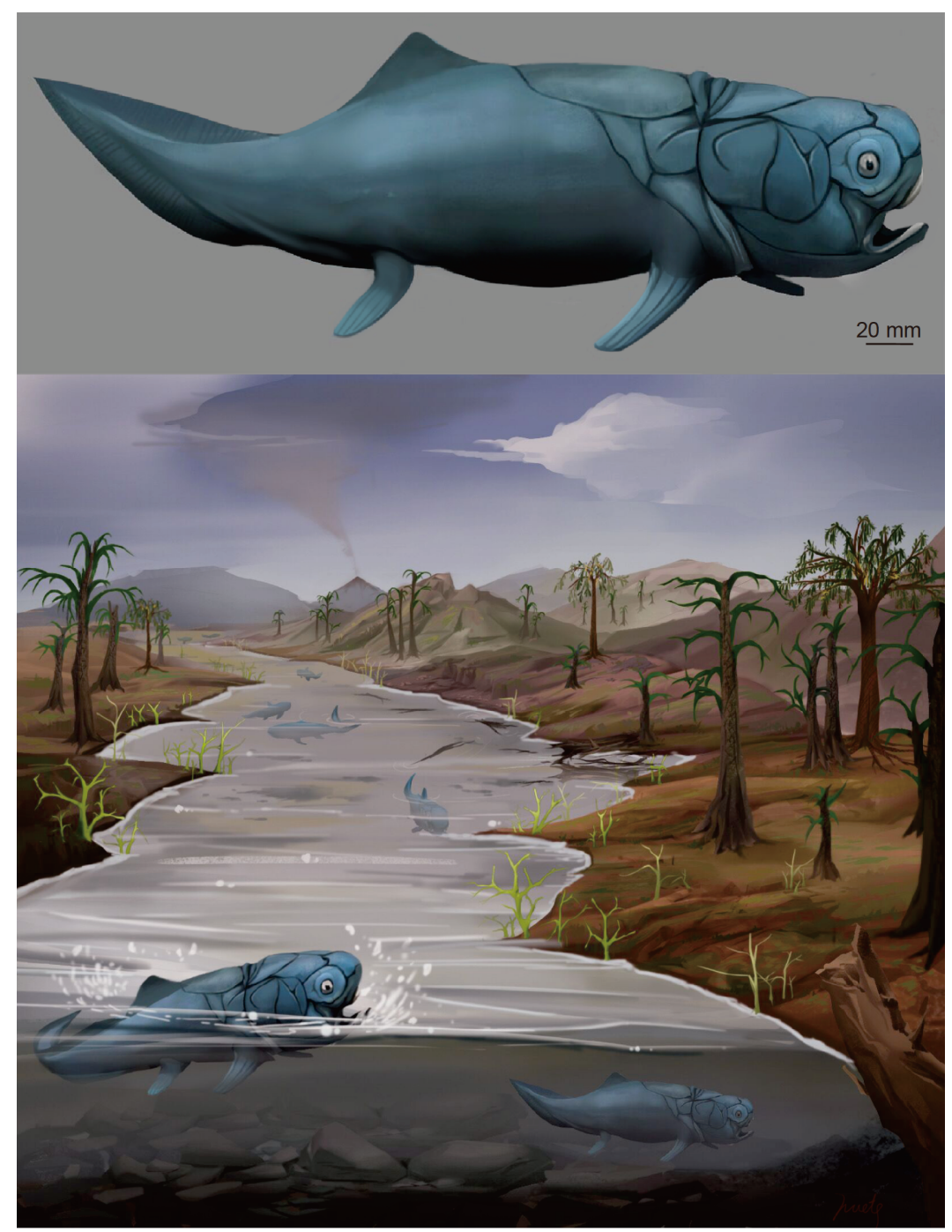

图 6 (网络版彩色)晚泥盆世短胸节甲鱼类——布龙鱼及其生态环境复原图

Figure 6 (Color online) Reconstruction of the Late Devonian Brachythoraci Bulongosteus and its ecological environment 
表明缺棘短胸节甲鱼类并非仅生活于滨-浅海环境，也 能生活于河流环境，甚至辫状河等淡水环境(图 1，6), 同时为至少一种缺棘短胸节甲鱼类通过迁徙进人淡水 环境提供了实证.

缺棘短胸节甲鱼类化石一直在海相地层中被发现， 首次在陆相沉积中的发现为布龙鱼的生活习性蒙上了 神秘的面纱，说明布龙鱼至少在其生活史中的某一时 段可生活于淡水环境中. Goedert等人 ${ }^{[33]}$ 通过研究格陵 兰岛东部和中国的泥盆纪脊椎动物骨骼的氧和硫同位 素后提出，包括早期四足动物在内的晚泥盆世多种脊 椎动物都是广盐性生物, 它们生活在盐度变化剧烈的 过渡水体环境中，同时认为盾皮鱼类比同时代的肉鳍 鱼类和四足动物可能更能适应更大的盐度范围. 布龙 鱼在西准噶尔朱鲁木特组中的发现表明，它们可能同 晚泥盆世众多鱼类一样也是一类广盐性鱼类.

\section{4 结论}

（1）记述了短胸节甲鱼亚目月骨鱼科一新属 布龙鱼(Bulongosteus gen. nov.), 新属的主要特征是: 中 颈片呈前缘前凸、后缘前凹的三角形，两侧微内凹. 副 颈片后缘超过中颈片后缘, 发育两条感觉管. 眀前片加 大以致形成眼眶的前背缘，表面具有较为密集的瘤点. 缘片前缘加厚形成眼眭后缘，3条感觉管呈明显“Y”字 形. 后腹侧片细长.

（2）布龙鱼的发现是节甲鱼类在新疆的首次发现， 也是我国第一个较完整的缺棘短胸节甲鱼类的发现, 更是世界上第一个在陆相沉积中发现的缺棘短胸节甲 鱼类化石．新材料的发现极大地扩展了缺棘短胸节甲 鱼类的地理分布和生态范围，同时说明缺棘短胸节甲 鱼类与晚泥盆世众多鱼类一样也是一类广盐性鱼类.

致谢中国科学院古脊椎动物和古人类研究所朱敏研究员和朱幼安副研究员给予本研究诸多指导和中肯建议, 中国科学院古 脊椎动物和古人类研究所盖志琨副研究员和中国科学院南京地质古生物研究所宋俊俊博士提供部分文献资料, 中国地 质大学(武汉)艺术与传媒学院杨倩瑜协助绘图, 参加野外工作的还有中国地质大学(武汉)的冯柏林、宋英凡和赵爽, 研 究过程中也得到中国地质大学(武汉)大学生基础科研训练计划项目和地球科学学院科研立项项目的鼓励和资助，在此 一并表示感谢.

\section{参考文献}

1 Rücklin M. First selenosteid placoderms from the eastern Anti-Atlas of Morocco; osteology, phylogeny and palaeogeographical implications. Palaeontology, 2011, 54: 25-62

2 Zhu M, Yu X, Ahlberg P E, et al. A Silurian placoderm with osteichthyan-like marginal jaw bones. Nature, 2013, 502: 188-193

3 Zhu M, Ahlberg P E, Pan Z, et al. A Silurian maxillate placoderm illuminates jaw evolution. Science, 2016, 354: $334-336$

4 Brazeau M D, Friedman M. The origin and early phylogenetic history of jawed vertebrates. Nature, 2015, 520: 490-497

5 Anderson P S L. Using linkage models to explore skull kinematic diversity and functional convergence in arthrodire placoderms. J Morphol, 2010, 271: 990-1005

6 Young G C. New arthrodires (Family Williamsaspididae) from Wee Jasper, New South Wales (Early Devonian), with comments on placoderm morphology and palaeoecology. Acta Zool, 2009, 90: 69-82

7 Young G C. Placoderms (armored fish): Dominant vertebrates of the Devonian period. Annu Rev Earth Planet Sci, 2010, 38: 523-550

8 Zhu Y A. Morphology and phylogeny of two brachythoracid arthrodries from the Devonian of China (in Chinese). Doctor Dissertation. Beijing: Graduate School of Chinese Academy of Sciences, 2014 [朱幼安. 中国泥盆纪两种短胸节甲鱼类形态学与分支系统学研究. 博士学位论文. 北 京: 中国科学院研究生院, 2014]

9 Carr R K. Reanalysis of Heintzichthys gouldii (Newberry), an aspinothoracid arthrodire (Placodermi) from the Famennian of northern Ohio, with a review of brachythoracid systematics. Zool J Linn Soc, 1991, 103: 349-390

10 Dupret V, Zhu M, Wang J Q. Redescription of Szelepis Liu, 1981 (Placodermi, Arthrodira) from the Lower Devonian of China. J Vertebr Paleontol, 2017, 37: e1312422

11 Young G C, Burrow C J, Long J A, et al. Devonian macrovertebrate assemblages and biogeography of East Gondwana (Australasia, Antarctica). Palaeoworld, 2010, 19: 55-74

12 Rücklin M. A new Frasnian placoderm assemblage from the eastern Anti-Atlas, Morocco, and its palaeobiogeographical implications. Palaeoworld, 2010, 19: 87-93

13 Zhu Y A, Zhu M. A redescription of Kiangyousteus yohii (Arthrodira: Eubrachythoraci) from the Middle Devonian of China, with remarks on the systematics of the Eubrachythoraci. Zool J Linn Soc, 2013, 169: 798-819 
14 Zhu Y A, Zhu M, Wang J Q. Redescription of Yinostius major (Arthrodira: Heterostiidae) from the Lower Devonian of China, and the interrelationships of Brachythoraci. J Linn Soc London Zool, 2015, 176: 806-834

15 Rücklin M, Long J A, Trinajstic K. A new selenosteid arthrodire ('Placodermi') from the Late Devonian of Morocco. J Vertebr Paleontol, 2015, 35: e908896

16 Boyle J, Ryan M J. New information on Titanichthys (Placodermi, Arthrodira) from the Cleveland Shale (Upper Devonian) of Ohio, USA. J Paleontol, 2017, 91: 318-336

17 Denison R H. Handbook of Paleoichthyology Volume 2 - Placodermi. Stuttgart: Gustav Fischer Verlag, 1978

18 Carr R. A new aspinothoracid arthrodire from the Late Devonian of Ohio, U.S.A. Acta Geol Pol, 2018, 68: 363-379

19 Wang J Q, Zhu M. A new eubrachythoracid arthrodire from the Upper Devonian of Hunan, China (in Chinese). Vertebr Palasiat, 2004, 42: 154-161 [王俊卿, 朱敏. 湖南晚泥盆世短胸节甲鱼类一新属. 古脊椎动物学报, 2004, 42: 154-161]

20 Gong Y M, Zong R W. Paleozoic stratigraphic regionalization and paleogeographic evolution in western Junggar, northwestern China (in Chinese). Earth Sci J China Univ Geosci, 2015, 40: 461-484 [龚一鸣, 纵瑞文. 古生代地层区划及古地理演化. 地球科学-中国地质大学学报, 2015, 40: 461-484]

21 Xia F S. New knowledge on the age of Honggululeng Fromation in northwestern margin of Junggar Basin, Northern Xinjiang (in Chinese). Acta Micropalaeontol Sin, 1996, 13: 277-285 [夏凤生. 新疆准噶尔盆地西北缘洪古勒楞组时代的新认识. 微体古生物学报, 1996, 13: 277-285]

22 Chen X Q, Mawson R, Suttner T J, et al. Late Devonian (Latest Frasnian-Famennian) faunas from the 'Hongguleleng Formation' and the F-F Boundary in northern Xinjiang, NW China. In: Suttner T J, Hubmann B, Piller W E, eds. Berichte des Institutes für Erdwissenschaften, KarlFranzens-Universität Graz, Band 14: Paleozoic Seas Symposium (Abstract volume), 2009. 18-20

23 Suttner T J, Kido E, Chen X, et al. Stratigraphy and facies development of the marine Late Devonian near the Boulongour reservoir, northwest Xinjiang, China. J Asian Earth Sci, 2014, 80: 101-118

24 Ma X, Zhang M, Zong P, et al. Temporal and spatial distribution of the Late Devonian (Famennian) strata in the northwestern border of the Junggar Basin, Xinjiang, northwestern China. Acta Geol Sin-Engl Ed, 2017, 91: 1413-1437

25 Zhang X S. Late Devonian conodont biostratigraphy, event stratigraphy and chemostratigraphy in South China and western Junggar, NW China (in Chinese). Doctor Dissertation. Wuhan: China University of Geosciences, 2019 [张欣松. 华南与西准噶尔晚泥盆世牙形石生物地层、事件地层 和化学地层. 博士学位论文. 武汉: 中国地质大学, 2019]

26 Dou Y W, Sun Z H. On the Late Palaeozoic plants in northern Xinjiang (in Chinese). Acta Geol Sin, 1985, 1: 1-11 [窦亚伟, 孙喆华. 新疆北部晚 古生代植物概况. 地质学报, 1985, 1: 1-11]

27 Miles R S, Dennis K. A primitive eubrachythoracid arthrodire from Gogo, western Australia. Zool J Linn Soc, 1979, 66: 31-62

28 Wang J Q. New discovery of early Middle Devonian Brachythoracid (Placoderm fish) from Wuding region of Yunnan (in Chinese). Vertebr Palasiat, 1992, 30: 111-119 [王俊卿. 武定中泥盆世早期节甲鱼的新材料. 古脊椎动物学报, 1992, 30: 111-119]

29 Carr R K, Hlavin W J. Two new species of Dunkleosteus Lehman, 1956, from the Ohio Shale Formation (USA, Famennian) and the Kettle Point Formation (Canada, Upper Devonian), and a cladistic analysis of the Eubrachythoraci (Placodermi, Arthrodira). Zool J Linn Soc, 2010, 159: 195222

30 Stensiö E A. Anatomical studies on the arthrodiran head. Part 1. Preface, geological and geographical distribution, the organization of the head in the Dolichothoraci, Coccosteomorphi and Pachyosteomorphi. Taxonomic appendix. K Sven Vetenskapsakad Handl, 1963, 9: 1-419

31 Xiao W, Huang B, Han C, et al. A review of the western part of the Altaids: A key to understanding the architecture of accretionary orogens. Gondwana Res, 2010, 18: 253-273

32 McKerrow W S, Mac Niocaill C, Ahlberg P E, et al. The Late Palaeozoic relations between Gondwana and Laurussia. Geol Soc London Spec Publ, 2000, 179: 9-20

33 Goedert J, Lécuyer C, Amiot R, et al. Euryhaline ecology of early tetrapods revealed by stable isotopes. Nature, 2018, 558: 68-72 


\title{
The first aspinothoracid arthrodire from the Late Devonian continental strata are found in western Junggar, Xinjiang
}

\author{
Yilong Liu ${ }^{1}$, Ruiwen Zong $^{2}$ \& Yiming Gong ${ }^{1,2 *}$ \\ ${ }^{1}$ School of Earth Sciences, China University of Geosciences, Wuhan 430074, China; \\ ${ }^{2}$ State Key Laboratory of Biogeology and Environmental Geology, China University of Geosciences, Wuhan 430074, China \\ * Corresponding author, E-mail: ymgong@cug.edu.cn
}

Arthrodira is the most widely distributed and diversified subgroup of Placodermi, which itself is the most diverse major group of the Devonian jawed vertebrates. Arthrodires were traditionally divided into the basal, paraphyletic "Dolichothoraci" and the highly nested monophyletic Brachythoraci, the latter of which displays reduction of body armor. Among brachythoracids, the Coccosteomorphi and Pachyosteomorphi further form a nested monophyletic Eubrachythoracidi. The sister group relationship between Coccosteomorphs and Pachyosteomorphs has been supported by most phylogenetic analyses, but the basal members and their interrelationships in these two groups are still unstable. Coccosteomorphs and pachyosteomorphs are the most diverse arthrodires in the Middle and Late Devonian. Among them, coccosteomorphs are found in strata of the lacustrine and littoral-neritic facies, while the pachyosteomorphs are mostly marine. Selenosteidae, one of the most well-known families in Pachyosteomorphi, are found in marine strata of Europe, North America, and North Africa. Junqing Wang found the nuchal plate of suspected Selenosteidae in the Xiejingsi Formation (early Famennian, Late Devonian) in Hunan Province, China, but due to the lack of identification features of the material, its exact systematic position awaits further determination.

The Zhulumute Formation is a lithological unit in western Junggar, Xinjiang of northwest China and is mainly composed of conglomerates, pebbly sandstones and medium- to coarse-grained sandstones, with typical braided stream lithofacies. Channel-fill deposits are thick, with well-developed parallel bedding, scour structure, and large-scale trough, wedge and tabular cross-beddings. This part contains a large number of plant stem fossils in fragment. The fine-grained floodplain deposits are thin, with horizontal beddings and small sand ripple beddings; fine fragments of plant stems or leaves can be seen in the siltstones. These characteristics indicate that the Zhulumute Formation in the Bulongguoer area was formed in the braided stream environment. At the same time, according to the preserved plant fossil Leptophloeum rhombicum, its age is limited to the early Famennian.

Here we report on a new selenosteid genus Bulongosteus, collected from the upper part of the Zhulumute Formation. The diagnostic characters of the new genus include: (1) A triangular nuchal plate with convex front edge, concave back edge and bilateral micro concave, and the side edge is overlaid with paranuchal plate; (2) the posterior margin of the paranuchal plate longer than that of the nuchal plate, and two sensory tubes were developed; (3) the preorbital plate enlarged to form the anterolateral margin of the orbit, with dense tumor spots on the surface; (4) the anterior edge of the marginal plate thickened to form the posterior margin of the orbit, and the three sensory tubes in the shape of "Y"; (5) a slender posterior ventrolateral plate. Pachyosteus, Rhinosteus, Melanosteus, and Walterosteu are similar to Bulongosteus in Selenosteidae. In Rhinosteus, there are a few tumor spots on the surface of the bone and the distribution of the sensory tubes of the paranuchal plate is different from Bulongosteus. The posterior margin of Walterosteu is wider than Bulongosteus, and the distribution of the sensory tubes of the paranuchal plate is different. The characteristics of Pachyosteus and Melanosteus are the most similar to Bulongosteus, but the distribution of the sensory tubes in their paranuchal plate is different from Bulongosteus. And Pachyosteus has less tumor spots in the nuchal plate and has a trapezoid rostral plate. Melanosteus has some tumor spots in the preorbital and suborbital plate.

Bulongosteus is the first arthrodire reported from Xinjiang of northwest China, and also the first relatively complete aspinothoracid reported in China. Strikingly, Bulongosteus is the first aspinothoracid arthrodire found in the continental strata in the world. The discovery of the new material significantly expands the geographical and ecological distribution of aspinothoracid arthrodires, and also shows that aspinothoracids, like many fishes in the Late Devonian, are euryhaline.

\section{Placodermi, Brachythoraci, Bulongosteus, Late Devonian, fluvial facies, western Junggar}

